\title{
THE EFFECT OF WELFARE PAYMENTS \\ ON THE MARRIAGE AND FERTILITY \\ BEHAVIOR OF UNWED MOTHERS: \\ RESULTS FROM A TWINS EXPERIMENT
}

\section{Jeff Grogger}

Stephen G. Bronars

Working Paper 6047

\section{NATIONAL BUREAU OF ECONOMIC RESEARCH 1050 Massachusetts Avenue \\ Cambridge, MA 02138 \\ May 1997}

This work has been supported by NICHD under grant number R01HD2488-1. We thank Nick Ronan and Mike Willis for invaluable research assistance, and Orley Ashenfelter, Rob Fairlie, Robert Moffitt, Steve Trejo, and seminar participants at the Institute for Research on Poverty, the NBER Summer Institute, and the RAND Conference on New Advances in Welfare Research for helpful comments. We take responsibility for any errors. This paper is part of NBER's research programs in Labor Studies and Public Economics. Any opinions expressed are those of the authors and not those of the National Bureau of Economic Research.

(C) 1997 by Jeff Grogger and Stephen G. Bronars. All rights reserved. Short sections of text, not to exceed two paragraphs, may be quoted without explicit permission provided that full credit, including $\odot$ notice, is given to the source. 
The Effect of Welfare Payments on the Marriage and Fertility Behavior of Unwed Mothers: Results from a Twins Experiment

Jeff Grogger and Stephen G. Bronars

NBER Working Paper No. 6047

May 1997

JEL Nos. I3, J1

Labor Studies and Public Economics

\begin{abstract}
We study one aspect of the link between welfare and unwed motherhood: the relationship between benefit levels and the time-to-first-marriage and time-to-next-birth among women whose first child was born out of wedlock. We use twin births to generate effectively random variation in welfare benefits among mothers within a state, which allows us to control for unobservable characteristics of states that typically confound the relationship between welfare payments and behavior. The twins approach yields evidence that higher base levels of welfare benefits: (1) lead initially unwed white mothers to forestall their eventual marriage; and (2) lead initially unwed black mothers to hasten their next birth. The magnitudes of these effects are small, however. Moreover, we find no evidence that the incremental benefit paid upon the birth of an additional child affects fertility.
\end{abstract}

Jeff Grogger

Department of Economics

University of California

Santa Barbara, CA 93106

and NBER

jeff@econ.ucsb.edu
Stephen G. Bronars

Department of Economics

University of Texas

Austin, TX 78712

bronars@mundo.eco.utexas.edu 


\section{Introduction}

The main cash welfare program in the United States--Aid to Families with Dependent Children, or AFDC-- historically provided benefits only to poor unmarried parents who lived with their children. For this reason, welfare has been blamed for the recent fall in marriage and the concomitant the rise in divorce. The increase in out-ofwedlock childbearing, which now accounts for 30 percent of all births in the United States, also has been attributed to the welfare system (Murray 1984).

In this paper we study the link between welfare and out-of-wedlock childbearing, but we focus on a set of issues that the literature has not addressed. We study initially unwed mothers, that is, women who were not married at the time of their first birth. Until these women marry, as many eventually do, they meet two of the three conditions required to receive AFDC: they have a child but no spouse. Many unwed mothers are also poor, thereby passing the means test as well. We ask whether higher welfare benefits cause initially unwed mothers to: (1) forestall their eventual marriage; or (2) hasten the birth of their next child.

There are several reasons why these questions deserve particular attention. First, initially unwed mothers participate in the welfare system at a high rate. Moore et al. (1993) have estimated that more than half of all unwed mothers who were 25 or younger at the time of their first birth receive welfare within the first five years of their child's life.

Second, not only do initially unwed mothers use welfare at a high rate, but out-ofwedlock childbearing accounts for a substantial fraction of welfare expenditures. Bane and Ellwood (1983) find that roughly one-third of all AFDC spells begin with the birth of 
a child to an unmarried and previously childless woman. They also report that such spells last substantially longer on average than spells precipitated by a divorce or a drop in earnings. Moreover, they find that unwed mothers are less likely to exit a welfare spell via marriage than previously married welfare recipients. If welfare payments have strong effects on the subsequent marital decisions of initially unwed mothers, then welfare payments may explain why unwed mothers' welfare spells tend to last so long.

Finally, welfare benefits rise with family size, a feature that appears to provide an incentive for welfare recipients to have more children. Potentially, such incentives could account for a substantial fraction of out-of-wedlock births: recent data show that more than half of all children born out of wedlock result from their mothers' second, third, or higher-order births (Moore 1995). The issue of welfare mothers having welfare babies animated much of the recent Congressional debate over welfare reform, and it is likely to arise repeatedly as states devise and implement their new welfare plans under the Personal Responsibility and Work Opportunity Reconciliation Act of 1996.

Our approach to estimation is novel in that it uses twin births to generate random variation in welfare benefits among unwed mothers within a state. This idea is easiest to explain by way of a thought experiment. Assume for simplicity that real benefits are constant over time and that all spells are fully observed, that is, not censored. Consider two women who live in the same state and ultimately become unwed mothers. Because both become unwed mothers, they share much in common. Given their preferences for children, marriage opportunities, labor market opportunities, and their state's level of welfare generosity, both pursue unwed motherhood from among the various options 
facing them. At the time of their first birth, however, one woman has twins, whereas the other has a singleton. Due to a random fertility event, their family sizes now differ. Because their family sizes differ, the mothers qualify for different benefits. Thus the mothers would forego different welfare payments if they were to marry.

If twins had no other effect on their mother's behavior, we could use this difference in benefit levels by family size to estimate the effects of welfare payments on the mother's time-to-first-marriage and time-to-next-birth, implicitly controlling for all state-specific factors such as labor market and marriage market conditions. Indeed since twin births are randomly distributed across the population, this approach also controls implicitly for all factors specific to the mother that may influence her subsequent marital and fertility behavior.

However, welfare benefits are not all that vary between the two mothers: one has one child, and the other has two. Even in the absence of benefit differentials, we would expect twins mothers to behave differently than singleton mothers for reasons attributable purely to having twins. Presumably, twins change the rate at which the mother receives marriage offers, and may affect the attractiveness of those offers as well. Twins likewise may lead the mother to desire a longer interval before her next birth.

Provided that these pure twins effects do not vary across states, however, we may still be able to identify the effects of welfare benefits. What we require are data on a second pair of unwed mothers from a different state with a different benefit schedule. We then can difference the data within state, relating differences in spell lengths between twin and singleton mothers to differences in the benefit levels to which those mothers are 
entitled. This approach identifies the effect of welfare while controlling for differences in family size.

In the next section we discuss some of the prior research on the link between welfare, marriage, and fertility. We then outline a stylized model of marital search that helps further motivate our approach. Next we consider estimation issues, accounting for the complications that arise from time-varying benefits, censored spells, and duration dependence. After presenting the main estimation results, we conclude with some simulations that illustrate the importance of welfare benefits in determining the behavior of initially unwed mothers.

\section{Prior Research}

Although our study is the first to address the effects of welfare on unwed mothers' time-to-first marriage and time-to-next-birth, previous researchers have analyzed several closely related issues. For some time, analysts have studied the effects of welfare benefits on marriage, divorce, and the formation of female-headed families. ${ }^{1}$ More recently, researchers have begun to focus on out-of-wedlock childbearing as well. ${ }^{2}$ Most of the studies of non-marital childbearing have focused on out-of-wedlock first births, however, or on out-of-wedlock birth rates, rather than on the higher-order fertility of initially unwed mothers. To our knowledge, no one has analyzed these mothers' postprimiparous marital behavior.

I Moffitt (1992) provides an exhaustive survey of the literature that analyzes the relationship between welfare, marriage, and divorce.

${ }_{2} \quad$ Moffitt (1995) surveys this literature. 
All of the previous studies, and indeed most studies of welfare incentives of any kind, share an important feature. At a given point in time, welfare benefits vary only across states, at least for a given family size. The problem for inference is that many other factors also vary across states, such as labor markets, marriage markets, and cultural norms. Moreover, these factors may be related to welfare benefits. To identify the effects of the welfare system, the researcher must isolate the effect of welfare benefits from the influences of other factors that vary across states.

Different authors have taken different approaches to this problem. Most have pursued a conditioning strategy of one kind or another, including in their regression models numerous observable characteristics of the state (Moore and Caldwell 1977; Ellwood and Bane 1985; Plotnick 1990; Lundberg and Plotnick 1990, 1995; Robins and Fronstin 1993; Schultz 1994). It is likely, however, that unobserved characteristics remain. For example, one can condition on the average accepted wage among working women in the state, but it is harder to condition on the average offered wage, which arguably provides a better measure of labor market opportunities. The difference between mean accepted and offered wages both may vary across states and may be related to welfare benefits. Likewise, cultural norms are difficult to measure, but may affect both fertility and the level of welfare benefits in a state.

A few studies have dealt with this problem explicitly by using within-state variation over time to estimate the effects of welfare payments on various outcomes (Ellwood and Bane 1985, Jackson and Klerman 1995, Hoynes 1995). If state-specific unobservables do not vary over time, then this approach eliminates them, and the effects 
of welfare may be identified. If changes in benefit levels are related to changes in unobservables within a state, however, then this approach may yield inconsistent estimates of the effects of welfare payments.

An alternative strategy to deal with state-specific unobservables has been pursued by Ellwood and Bane (1985). Their approach is to use the relationship between welfare payments and family size to generate variation in benefits within states. Although they use this strategy to study divorce rates among married women, rather than marriage and fertility among unmarried women, their approach is worth discussing in some detail because it is closely related to ours.

Ellwood and Bane (1985) compare within-state differences in divorce rates between married women with children and married women without children to the difference in welfare benefits between the two groups of women (for married women, benefits are zero). If the average difference in unobservables between mothers and childless women does not vary across states, then this approach may identify the effects of welfare payments. If women self-select into motherhood on the basis of unobservables that are correlated with benefits, however, then this strategy yields inconsistent estimates. $^{3}$

Our approach is related to Ellwood and Bane's in that we use variation in benefits by family size to generate within-state variation in welfare payments. There are some important differences between our studies, however. First, we compare mothers with two

$3 \quad$ Ellwood and Bane (1985) also use within-state variation in benefits to study non-marital childbearing, where the within-state variation arises due to differences in martial status. Similar criticisms apply to that approach as well. 
children to mothers with one child, rather than comparing mothers to childless women. Second, we study marriage and fertility among initially unwed mothers, rather than divorce among married women. Finally, and most important methodologically, the variation in family size that we exploit arises due to a random event: the birth of twins.

Since twins births are random, they lead to random variation in family size, which in turn provides us with random variation in benefits. ${ }^{4}$ We use this variation to estimate the effects of welfare benefits on the mother's time to her first marriage and time to her next birth. In both cases, we start the clock with the birth of her first child, which is the time at which she becomes categorically eligible to receive AFDC. An illustrative model of marital search helps to motivate this approach.

\section{Theoretical Framework}

In a stationary environment, the duration of an initially unwed mother's marital search will be a function of the distribution from which she draws marriage offers, the arrival rate of marriage offers, and her reservation offer. Her reservation offer in turn will be a function of her labor market earnings if she works, and of her welfare benefits if she does not. Because of layoffs and job turnover, welfare benefits also may enter the decisions of women who are currently employed. ${ }^{5}$

Assuming that marriage offers are independent over time and that all women marry during the sample period, so that no spells are censored, the search model motivates a regression of the mother's time to first marriage on determinants of the

4 Actually, the likelihood of having twins depends on the mother's race and age at birth (Mittler 1971). Since we can condition on both of these factors, this presents no problem for the analysis, and we can think of twin births as being effectively random. See Rosenzweig and Wolpin (1980).

5 A comprehensive structural model would account explicitly for interactions between marriage, fertility, and employment decisions. Such a model is beyond the scope of this paper, however. 
marriage offer distribution and determinants of the reservation offer. Determinants of the reservation offer include the level of welfare benefits and the number of children, which are observable; the mother's labor market opportunities, which are observable if she works; and her tastes for children, which are unobservable altogether. Determinants of the marriage offer distribution include the (observable) number of children and many unobservable characteristics. A reduced-form model that can be estimated from data on twin births takes the form: ${ }^{6}$

$\ln t_{i j}^{k}=\alpha W_{i}^{k}+\gamma T_{i j}^{k}+\mu_{i}+\varepsilon_{i j}^{k}, \quad i=1, . ., n ; j=1, \ldots, m_{i}^{k} ; k=1,2$.

The variable $t_{i j}^{k}$ denotes the time-to-first-marriage for the $j$ th initially unwed mother in state $i$ with $k$ children at her first birth, where $k=1$ denotes a singleton birth and $k=2$ a denotes a twin birth. The variable $W_{i}^{k}$ denotes the maximum base welfare benefit payable to mothers with $k$ children in state $i$. This is the 2-person benefit guarantee for singleton mothers (i.e., the benefit for a family consisting of one mother and one child) and the 3-person guarantee for twins mothers. The variable $T_{i j}^{k}$ is a twins dummy, equal to 1 if $k=2$ and equal to zero otherwise. The variables $\mu_{l}$ and $\varepsilon_{i j}^{k}$ are unobservable determinants of the mother's marriage offer distribution and reservation offer. The term $\mu_{i}$ reflects unobservables common to all women in a state, such as the general state of the marriage market, whereas $\varepsilon_{i j}^{k}$ captures unobservables idiosyncratic to the mother such as her labor market productivity. The terms $\alpha$ and $\gamma$ are parameters to be estimated. In

\footnotetext{
6 In addition to the stationarity and independence assumptions previously stated, this specific functional form relies on the assumptions that marriage offers follow a Pareto distribution with a finite first moment, that rejected marriage offers cannot be recalled, and that marriages last forever. See Devine and Kiefer (1991, chs. 2 and 3). The distributional assumptions are needed only for this illustrative example, and are relaxed in the empirical work.
} 
particular, $\alpha$ measures the proportionate impact of a change in benefits on the expected time to first marriage. There are $n$ states in the sample, and in the $i$ th state, there are $m_{i}^{k}$ initially unwed mothers who had $k$ children at their first birth.

One approach to estimating equation (1) is simply to regress log time-to-firstmarriage on welfare benefits, the twins dummy, and a vector of state dummies. Indeed in our empirical work we adopt a generalization of this approach. For analytical purposes, however, an equivalent grouped-data approach gives rise to a simple differencing scheme that illustrates several important features of the model.

To pursue the grouped data approach, first average separately over twin and singleton mothers within each state. This yields

$\overline{\ln t_{i}^{2}}=\alpha W_{i}^{2}+\gamma+\mu_{i}+\overline{\varepsilon_{i}^{2}}$

for mothers of twins, and

$$
\overline{\ln t_{i}^{\top}}=\alpha W_{i}^{1}+\mu_{i}+\overline{\varepsilon_{i}^{\top}}
$$

for mothers of singletons, where $\bar{z}_{i}^{k}=\frac{1}{m_{i}^{k}} \sum_{j=1}^{m_{i}^{k}} z_{i j}^{k}$. Differencing within states yields a grouped-data estimating equation:

$$
\overline{\ln t_{i}^{2}}-\overline{\ln t_{i}^{1}}=\alpha\left(W_{i}^{2}-W_{i}^{1}\right)+\gamma+\overline{\varepsilon_{i}^{2}}-\overline{\varepsilon_{i}^{1}}, \quad i=1, \ldots, n
$$

Differencing has eliminated $\mu_{i}$ from the model. Thus the effect of welfare benefits can be estimated by a regression of the difference in mean (log) durations between twins and singleton mothers by state on a constant and the difference in benefits between mothers with two children and mothers with one child. In order for this 
regression to yield consistent estimates of the effects of welfare payments, we need for the difference in average idiosyncratic unobservables between twins and singleton mothers, that is, in $\overline{\varepsilon_{i}^{2}}-\overline{\varepsilon_{i}}{ }^{\top}$, to be uncorrelated with the difference between two- and onechild benefit levels across states. The twins experiment guarantees this. Because twins are a random event, the average tastes, labor market opportunities, and (ex ante) marriage opportunities facing twins and singleton mothers within a state are the same. In contrast, twin and singleton mothers face different benefits. Thus the difference in average unobservables is uncorrelated with the difference in benefits.

From equation (2) we can deduce a number of identification conditions. The first concerns the assumption that the pure twins effect does not vary by state. If the constant $\gamma$ were replaced by $\gamma_{i}, i=1, \ldots, n$, then there would be exact collinearity between the $\gamma_{i}$ terms and the welfare differential. Thus the identifying assumption that the pure twins effect does not vary by state is fundamental to the approach. Similarly, $\gamma$ must be constant over calendar time.

Another implicit identifying assumption is that the marginal effect of welfare payments, $\alpha$, is the same for twins and singleton mothers. Unfortunately, it is difficult to provide primitive conditions on preferences under which this condition would hold. A heuristic explanation is that the higher payment made to the twins mothers must compensate them for their extra children in such a way as to leave the marginal effects of benefits the same for both them and their counterparts who have singletons.

Equation (2) also illustrates why comparing general samples of mothers with one and two out-of-wedlock children may yield inconsistent estimates of $\alpha$. Without the 
twin-birth fertility shock, women with two out-of-wedlock children are a self-selected sample whose (unobservable) individual characteristics and marriage market prospects may be quite different from those of women with one out-of-wedlock child. Thus selfselection may cause the difference in average unobservables within a state to be correlated with the difference in benefits. For example, an unmarried mother with one child and given marriage market prospects may forestall her next birth if two-child benefits are low, but have an additional out-of-wedlock birth if benefits are high enough. Put differently, the difference in average marriage market prospects between women with two children and women with one child may vary across states as a function of the benefit differential. Put differently still, the composition of mothers willing to have a second out-of-wedlock birth may depend on benefits. Thus in a regression such as equation (2) without twins, the estimate of $\alpha$ would reflect not only the effects of welfare payments, but also the correlation between benefits and average unobservables that arises through self-selection.

Although the discussion above has been couched in terms of the mother's postprimiparous marital behavior, similar factors are likely to influence her subsequent fertility as well. Higher base benefits provide greater income, so if children are normal goods, one expects higher base benefits to encourage additional childbearing. Likewise, higher marginal benefits upon the birth of the next child, all else equal, presumably would make subsequent childbearing more attractive. Thus the model in equation (1), 
with $t_{i j}^{k}$ redefined to denote time to the next birth, and augmented by marginal benefits, provides a basis for estimating the effect of welfare benefits on subsequent fertility. ${ }^{7}$

\section{Estimation}

In the stylized setting discusșed so far, estimation can be carried out in a particularly simple manner. Within states, one first averages durations among twins mothers and durations among singleton mothers. One then differences these average durations within state, and regresses the state-level differences in durations on a constant and state-level differences in welfare benefits.

There are several complications, however, that require a more elaborate treatment than this simple differencing approach. First, many spells are censored, both for time-tofirst-marriage and time-to-next-birth. Second, the spells exhibit duration dependence: the likelihood of exiting a spell at any given time depends on the elapsed duration of the spell at that time. Finally, benefits are not constant, but rather vary with calendar time.

A hazard model provides the means for generalizing the framework above to account for these complications. In a hazard model, we posit that the probability of ending a spell in any given period is a function of the elapsed duration of the spell, welfare benefits, the twin birth dummy, and state dummies. Since our duration data are measured as the number of calendar quarters since the birth of the first child, a discretetime model is appropriate. We have:

$P\left(t_{i j}^{k}=\tau+1 \mid t_{i j}^{k}>\tau ; B_{i s}^{k}, T_{i j}, D_{i}\right)=g\left(B_{i s}^{k}, T_{i j}, D_{i}, \tau\right)$

\footnotetext{
$\overline{7}$ We enter base and marginal benefits separately because changes in base benefits (i.e., one-child benefits for singleton mothers and two-child benefits for twins mothers) affect behavior only via an income effect, whereas changes in marginal benefits may give rise to both income and substitution effects.
} 
where $\tau=1,2, \ldots$ is the elapsed duration of the spell, $B_{i s}^{k}$ denotes benefits paid to a mother with $k$ children by state $i$ at calendar date $s$, and $g()$ satisfies the requirements of a cumulative distribution function.

In this framework, each spell is represented as a sequence of $(0,1)$ observations. A mother who marries $\tau+1$ quarters after her first birth contributes $\tau+1$ observations to the sample, of which the first $\tau$ are zeroes, with associated probability $1-g()$, and the last is a one, with associated probability $g()$. Similarly, a mother whose unmarried spell is censored at time $\tau+1$ contributes $\tau+1$ observations, all of which are zeroes. ${ }^{8}$

A convenient functional form for $g()$ is the logistic c.d.f. Duration dependence is treated non-parametrically by including a full set of dummy variables for elapsed duration, that is, separate dummies for each value of $\tau$. If real welfare benefits were constant over time, this logistic discrete-time hazard model could be fit by generating a $(0,1)$ dummy for each quarter of each mother's spell, then estimating a logit model using these binary sequences as the dependent variable, and benefits, the twin birth dummy, the duration dummies, and the state dummies as explanatory variables.

In the presence of time-varying benefits, however, it need not follow that unobservable characteristics of twin and singleton mothers from the same state are equal on average. This is because unwed mothers from different maternity cohorts, i.e., who give birth in different years, may face different incentives. Although all mothers in a state who have out-of-wedlock births in any year face the same labor markets, marriage markets, and benefits on average, regardless of whether they ultimately bear twins or a

$8 \quad$ Kiefer (1988) and Sueyoshi (undated) discuss this approach to discrete-time hazard models. 
singleton, the same cannot be said for mothers who bear children in different years, because women of different maternity cohorts may be eligible for different benefits. A woman willing to pursue unwed motherhood in a year when benefits are high may be unwilling to take such a risk in a year when benefits are low. Thus there may be differences in the average unobservable characteristics of mothers across maternity cohorts in the same state. Therefore if we were to condition only on the mother's state, welfare benefits would vary not only due to the random variation in family size caused by twin births, but also due to time variation in benefits across maternity cohorts. Because cross-cohort variation is non-random, conditioning only on states in our hazard model may lead to inconsistent estimates.

Fortunately, the solution to this problem is simple, at least conceptually. Since mothers within a state who give birth in the same year face the same incentives, we condition not on state alone, but on state interacted with maternity cohort. Therefore in the logistic discrete-time hazard models reported below, we include benefits, the twin birth dummy, the duration dummies, and a full set of state-maternity cohort dummies. Because the probability of giving birth to twins is related to the mother's age at birth, we also include her age at first birth in the model. To allow for time trends, we also include the calendar year corresponding to each of the binary observations. ${ }^{9}$

\footnotetext{
$9 \quad$ We have also fit models in which benefits were entered as logs rather than levels. Those estimates were qualitatively and quantitatively similar to the estimates presented below.
} 


\section{The Data}

\section{A. The Sample of Initially Unwed Mothers}

Our samples of initially unwed mothers are drawn from the 1980 Census PUMS

files. With three exceptions, the samples are similar to those which we analyzed in Bronars and Grogger (1994). Here we describe only the most important features of our sampling scheme; for details, the reader is referred to our earlier study.

The hierarchical structure of the PUMS files allows the researcher to link mothers to their children, provided that they live in the same household. If the mother's first-born child still lives at home, then the marital and fertility histories collected in the 1980 Census let us determine whether the mother's first birth occurred out of wedlock. To identify first births, we limited our sampling to households in which the number of children at home matched the mother's total reported fertility. If the mother's second child was the same age and born in the same calendar quarter as her first, then we flagged her as having twins at her first birth.

In our previous work we sampled mothers whose oldest child was 18 or younger.

Because AFDC benefits are not available prior to 1968 , we limit our sample here to mothers whose oldest child is 12 or younger. Whereas we previously limited ourselves to the A and B subsamples of the PUMS, for this project we have added the $\mathrm{C}$ subsample as well. In total, we identified 785 initially unwed mothers of twins. We also retained all singleton mothers to construct a comparison sample, rather than retaining only a 1 percent sample as we did before. This resulted in a sample of about 89,000 initially unwed singleton mothers. 
For a number of reasons, we are able to use only a fraction of these observations for this study. First, AFDC benefits for three-person families are available in only a limited number of states prior to $1975 .^{10}$ This lack of benefit data eliminates about 31,000 mothers from the estimation samples.

Further restrictions on the sample are necessary to identify the model. In order to estimate the coefficient for the dummy variable corresponding to a given state/maternity cohort cell, the cell must include at least one completed spell. Otherwise the maximization algorithm sets the coefficient to minus infinity and the observations for that cell contribute no information to the likelihood function. Furthermore, in order to contribute information regarding the effects of benefits, the cell must contain at least one twins mother. Together, these restrictions eliminated about 21,000 mothers from the samples used to analyze time-to-first-marriage, and about 22,000 from the samples used to analyze time-to-first-birth.

\section{B. Defining Welfare Benefits}

Over the 1968-1980 sample period, the AFDC program was the main cash welfare program in the United States, providing benefits almost exclusively to poor single mothers. ${ }^{11}$ Benefit schedules were set by the states subject only to minimal federal

\footnotetext{
10 Benefits for families of 2, families of 4 , and for families of 3 after 1974, are taken from U.S. Department of Health, Education, and Welfare, NCSS Report D-2 (various years). Benefits for families of 3 prior to 1975 are taken from U.S. Department of Health, Education, and Welfare, NCSS Report D-3 (various years). Three-person benefits are available for only a limited number of states. These states (and the first year for which benefits are available) are: Arkansas, California, Georgia, Indiana, Iowa, Mississippi, Missouri, Tennessee (1968); Arizona, Pennsylvania, Virginia (1969); D.C., Florida, Maryland, North Carolina (1970); Minnesota, New Jersey (1971); Texas (1973); Illinois, Massachusetts, South Carolina, Wisconsin (1974).

"Over the period from which our data are drawn, about half the states also offered benefits to married, unemployed parents under the AFDC-UP program. Its eligibility requirements are more stringent than those of the main AFDC program, and its participation rates are generally quite low.
} 
restrictions. AFDC participants were also eligible for food stamps (FS), however, whose benefit levels are set federally. Particularly in states with low AFDC payments, food stamp benefits constitute a sizable fraction of all cash and near-cash benefits. The base benefit included in our model is thus the sum of the maximum AFDC and FS benefit for a given family size, accounting for the interaction between the programs by which AFDC payments may reduce the family's FS benefit. In both the marriage and fertility models, the base benefit for singleton mothers is the benefit level for a family of two (i.e., for a family consisting of a mother and one child), and we assign twins mothers the benefit received by a family of three. In the fertility models we include an additional variable measuring the marginal benefit increase that the mother would receive upon the birth of her next child. For singleton mothers, this is the difference between 3-person and 2person benefits; for twins mothers, it is the difference between 4-person and 3-person benefits.

A problem arises in defining welfare benefits because the mother's state of residence is observed only twice: at the birth of her child and in 1980, when the Census data were collected. If the mother changes states between those periods, then the welfare benefits that we assign to her may be incorrect. Of the mothers whose state of residence in 1980 was observable, 13 percent had been living in another state at the time their child was born. Among the remainder, there is no way to determine how many had resided in one state the entire time, and how many had moved away but then returned. If initially unwed mothers move for reasons unrelated to welfare benefits, this problem gives rise to measurement error in welfare benefits. We would generally expect measurement error to 
bias our estimates toward zero. If welfare drives mobility, then our results may be biased in an unknown direction.

There seems to be no formal remedy to this problem. Our approach is to define benefits two ways: one by the mother's state of residence in 1980, and one by the state of her child's birth. This approach does nothing to solve the potential misspecification problems. To the extent that these two definitions of benefits yield similar parameter estimates, however, we may have greater confidence in our results than we would have otherwise.

\section{Sample Characteristics}

Summary statistics are presented by race in Tables 1 and 2 for the estimation samples and for the full sample of unwed mothers whose first birth occurred during or after 1968. Table l presents data for whites. Note that sample sizes vary depending on how benefits are defined. This is because the state of residence in 1980 was suppressed for about one-third of the mothers who were drawn from the PUMS B and C samples. In contrast, the state of the child's birth is defined for all mothers, although some children were born outside the U.S. The sample sizes also vary according to outcome because there are cells that meet all restrictions for one outcome but fail one or more of the restrictions for the other. For example, there are cells in which one marriage took place but in which there were no subsequent births. Because we can include only cells with at least one completed spell, such a cell would be included in the marriage sample but not in the birth sample. 
The second and third rows of the table show that the various sample restrictions lead to a reduction in the number of states and state/maternity cohort cells that are represented in the data. The next row shows that the geographic distribution of the estimation samples differs from that of the full sample. This is because populous states are more likely to meet our sampling criteria, which results in a relatively large number of mothers from California and a relatively small number of mothers from Midwestern states.

The mothers in the analysis samples come from states with average benefit levels, as shown in the next row of the table. Mean age at first birth varies little across the various samples. Twins mothers account for about 1.4 percent of the estimation samples.

The second panel of the table compares outcomes across samples. The women in the estimation samples are less likely to marry eventually than initially unwed mothers generally, but the differences are small. In general, about 62 to 64 percent of these women, all of whom are observed within 12 years of their first birth, marry eventually. Among those who marry, the time between the first birth and the wedding date was about 8 quarters on average; for those who had not married, the average elapsed spell measured about 14 quarters before it was censored. In both cases, spells were a bit shorter for women in the estimation samples than among initially unwed mothers generally. Unconditionally, the mean time between first birth and first marriage was just over 16 quarters, whereas the median spell was 11 quarters. ${ }^{12}$

12 The unconditional mean is calculated based on the assumption that spells are exponentially distributed. This estimate should be viewed as purely illustrative, since the duration dependence in the data are at clear odds with the exponential distribution. This assumption is not maintained in the regression analysis. 
About half of the mothers experienced a subsequent birth. Among those with subsequent births, the average time between births was about 12 quarters. Among those without subsequent births, the duration of the ongoing birth interval averaged about 16 quarters when the interval was censored. Unconditionally, the mean time between births was 33 quarters; the long interval arises due to the high fraction of censored spells. The median interval was 20 quarters.

Table 2 presents similar data for blacks. As one would expect, the geographic distribution of black mothers differs from that of white mothers, with a heavy concentration in the South. There are relatively more mothers from the South, and fewer from the Midwest, in the estimation samples than in the full sample. Mean benefit levels in the estimation samples vary slightly from those in the full sample.

The second panel of the table shows that initially unwed black mothers are much less likely to marry than their white counterparts. Whereas nearly 2 out of 3 white mothers had married by the Census date, only 40 percent of the black mothers had married. As a result, mean and median times to first marriage among blacks are substantially longer than those among whites. In contrast, subsequent births and birth intervals among black mothers are similar to those among their white counterparts.

\section{Results}

\section{A. Principal Findings}

Although the main focus of the paper is the estimates obtained using the twins approach to estimation described above, we first present in Table 3 some estimates obtained by fitting the logistic discrete-time hazard model to specifications that exclude 
the state/maternity cohort dummies. Given the discussion above, we have no reason to believe that these estimates have any favorable properties. We present them solely for purposes of comparison to the twins-approach estimates to follow.

For time-to-first-marriage, the benefits coefficients are negative for both races. Furthermore, the estimates are generally similar regardless how benefits are measured. Taken at face value, these estimates would suggest that higher benefits lead to lower marriage hazards. In other words, these estimates suggest that higher benefits lead to longer intervals between the birth of the first child and the mother's eventual marriage. All of the estimates are statistically significant.

In the fertility models, the base benefit coefficients are negative and significant for blacks, but of mixed sign and insignificant for whites. If one were to interpret these estimates at face value, one would draw the surprising conclusion that higher benefits lead black unwed mothers to delay their next birth. None of the coefficients on marginal benefits are remotely significant.

Table 4 presents estimates based on the twins approach. The regressors included in these specifications are welfare benefits, the twins dummy, the dummies for elapsed duration, the mother's age at her first birth, a time trend, and dummies for each state/maternity cohort cell. Thus the effect of welfare benefits in these models is identified solely by differences in benefits that arise due to random differences in family size.

For whites, the results based on the twins approach are similar to those from the models that exclude the state/maternity cohort dummies reported in Table 3. In the 
marriage model, the coefficients on welfare benefits are similar in magnitude and statistically significant. The negative sign indicates that higher benefits reduce the marriage hazard, lengthening the average time to first marriage. In other words, higher benefits lead initially unwed white mothers to delay their eventual marriage.

The results for the time-to-next-birth models, shown in panel B of Table 4, provide no evidence that welfare benefits affect the timing of the second birth for initially unwed white mothers. The coefficients on base benefits change sign between the two specifications, and neither is significant. For marginal benefits, the coefficients again vary as to sign, and neither coefficient is larger than its standard error.

For blacks the results are different. The coefficients for the models of time-tofirst-marriage are small and insignificant, indicating that blacks' marital behavior is unaffected by welfare benefits. In the fertility models, however, the coefficients on base benefits are positive and at least marginally significant. This says that higher base benefits are associated with a higher birth hazard. In other words, among initially unwed black mothers, higher base benefits hasten the arrival of the second child.

Marginal benefits, in contrast, have no effect on subsequent fertility. Although the marginal benefit coefficients are both positive, neither is significant at conventional levels. It is important to realize that recent policy proposals aimed at reducing the fertility of women receiving welfare have focused on limiting marginal, rather than base, benefits. We find no evidence to suggest that reducing marginal benefits would lead to reductions in fertility. 


\section{B. Specification Tests}

Of course, the twins-approach estimates are based on a number of assumptions which, if violated by the data, may give rise to biased results. One critical assumption is that the pure twins effect--the effect of twins on the mother's subsequent marriage and fertility decisions that would arise solely due to differences in the number of children-does not vary by state. Although this assumption cannot be tested directly, it can be tested indirectly, by testing for variation in the pure twins effect by region. Another assumption is that the pure twins effect is constant over the sample period. This assumption can be tested directly. The last assumption is that the effect of an additional dollar of welfare benefits is the same for twins and singleton mothers. This too can be tested.

Tables 5 and 6 present twins-approach estimates that allow us to test these various assumptions. Table 5 presents estimates for whites and Table 6 presents estimates for blacks. In both tables, estimates for time-to-first-marriage are presented in the top panel of the table, and estimates for time-to-next-birth are presented in the bottom panel. Columns (1) and (4) present estimates from models that include interactions between the twins dummy and dummies for Census regions. Columns (2) and (5) present estimates based on models that include an interaction between the twins dummy and the time trend. Columns (3) and (6) present estimates from models that include interactions between benefits and the twins dummy. In cases where we reject the null that the pure twins effect is constant by region, the models reported in the other columns also include the twinregion interactions. 
Focusing first on the models for whites, we find little evidence that the pure twins effect varies geographically. Regardless of how benefits are measured, the coefficients on the twin-region interactions are insignificant, both individually and jointly. The twintime trend interaction coefficients likewise are insignificant. The primary effect of adding this term is to decrease substantially the precision with which the main twins coefficient is estimated. Similarly, the twin-benefits interactions are insignificant, and have little effect on the main benefits coefficients.

For blacks the results are a bit different. In the marriage models the twin-region interactions are jointly significant at any level greater than 5 percent. Adding the interactions has no effect on the welfare coefficients, however, and in no way changes our conclusion that time-to-first-marriage among blacks is unaffected by welfare benefits.

In the fertility models, the twin-region interactions are insignificant, and adding the interaction terms has little effect on the estimated welfare coefficients. The effects of base benefits remain positive and at least marginally significant, whereas the marginal benefit coefficients remain positive but insignificant. The twin-time trend interactions are insignificant and have no effect on the welfare coefficients. Likewise, there are no significant interactions between benefit levels and the twins dummy, and including these terms has little effect on the main benefits coefficients.

Finally, in addition to estimating the logistic discrete-time hazard models reported above, we also estimated a (multinomial) logistic discrete-time competing risk model. In the competing risk model, we model the unwed mother's probability of exiting the state of simultaneously having one child and being an unwed mother. The mother exits the 
state either if she marries or if she gives birth to a subsequent child; the model allows welfare benefits (and the other regressors) to affect exits via marriage and exits via an additional birth differentially. In principle, the competing risk model may be better suited to the problem at hand, because by censoring birth intervals at the time of an intervening marriage, it incorporates the institutional restriction that welfare eligibility (and hence the effect of welfare on behavior) ends with marriage. In practice, however, the competing risk models yielded estimates that were similar to the single-risk models reported above. For this reason, we focus exclusively on the estimates reported above in the discussion below.

\section{Discussion}

Our estimation results can be summarized readily. Welfare benefits have no effect on time-to-first-marriage among blacks or time-to-first-birth among whites. Higher levels of base benefits do lead white mothers to delay their eventual marriage, however, and lead black mothers to hasten their next birth.

Because the coefficients of the logistic hazard models have no natural metric, however, it remains to assess the quantitative importance of these welfare incentives. In figures 1 and 2 we present estimated survivor functions based on actual and simulated benefit levels. Figure 1 plots survivor functions from the marriage model for whites, and Figure 2 plots survivor functions from the fertility model for blacks. In each case there are two figures, one for each definition of benefits. Because the coefficient estimates were so similar across the different definitions, the simulated survivor functions look similar as well. 
The function plotted in the middle of each figure is the estimated survivor function based on twins estimates of the logistic discrete-time hazard models. In figure 1, the plot on the left is based on the model reported in column (1) of Table 4, and the plot on the right is based on the model reported in column (2) of Table 4. In figure 2, the plot on the left is based on the model reported in column (3) of Table 4, and the plot on the right is based on the model reported in column (4) of Table 4.

The functions plotted with small circles (o) are simulated survivor functions obtained after reducing base benefits by 10 percent. The functions plotted with plus signs $(+)$ are simulated survivor functions based on a 10 percent increase in base benefits. Figure 1 suggests that time-to-first-marriage among initially unwed whites is fairly responsive to welfare payments. At any time after the first birth, the simulated survivor function reflecting higher benefits is notably higher than the baseline estimate, indicating that the fraction of mothers remaining unmarried is higher. Likewise, at any point in time, lower benefits are associated with lower survival rates, meaning that a higher proportion of mothers has married.

Figure 2 suggests that time-to-next-birth among initially unwed black mothers is comparably responsive to changes in base welfare benefits. At any point after the first birth, the survivor function reflecting higher benefits is notably lower than the baseline survivor function, indicating that a smaller fraction of women has not yet had a subsequent child. The survivor function reflecting lower benefits lies above the baseline, indicating that a larger fraction of women has foregone further childbearing. 
Tables 7 and 8 provide some numerical estimates to go with the plots. In the first row of Table 7 , we see that 30 percent of the initially unwed mothers marry within one year of their out-of-wedlock birth. If benefits had been 10 percent lower, the model predicts that the one-year marriage rate would have been about 32 percent; had benefits been 10 percent higher, it would have been 28.4 percent. Thus a 10 percent increase in base benefits leads to a 5.3 percent reduction in the fraction of white women who marry within one year of their first birth. After 5 years, about 68 percent of the initially unwed white mothers had married. With the higher level of benefits, only about 66 percent would have married; with the lower level of benefits, 70 to 71 percent would have married. For white unwed mothers, welfare policy appears to have important effects on subsequent marital timing.

Table 8 provides estimates from the fertility model for blacks. Within two years of their initial out-of-wedlock birth, 20 percent of black mothers had an additional child. If benefits had been 10 percent higher, the model predicts that 21 percent would have had additional children within two years; if benefits had been 10 percent lower, the figure would have been only 19 percent. For black unwed mothers, a 10 percent increase in base benefits increases the fraction of women who have another child within two years of the first by 5 percent.

\section{Conclusions}

The twins approach to estimation indicates that, for initially unwed white mothers, higher welfare benefits prolong the time between the mother's birth and her eventual marriage. The magnitude of this effect is rather modest, however. Our estimates indicate 
that a 10 percent decrease in welfare payments would raise the fraction of mothers who marry within a year of their first birth from 30 percent to about 32 percent. After five years, the fraction that marries would be 70 to 71 percent, rather than 68 percent.

The estimates also reveal a modest link between base welfare benefits and the subsequent fertility of initially unwed black mothers. Our estimates indicate that a 10 percent increase in base benefits would raise the fraction of mothers who have additional children within two years of their first birth from 20 to 21 percent. Within five years, 63 to 64 percent would have an additional child, rather than 62 percent.

It is important to stress that these fertility effects pertain only to base benefits. We find no significant link between the incremental welfare benefit paid to mothers upon the birth of subsequent children and the timing of those subsequent births. Thus we have provided no evidence that reducing incremental benefits along the lines of the family cap provisions in recent welfare reform legislation would reduce the number of births to initially unwed mothers.

Finally, we note that one of our main conclusions--that higher benefits lead to longer times-to-first-marriage among whites--has ambiguous implications for the wellbeing of the mother and her children. Because longer unmarried spells for the mother mean longer spells in single-parent households for the children, and there is ample evidence that longer spells in single-parent homes lead to lower educational attainment (Grogger and Ronan 1995), it is tempting to conclude that higher benefits could have deleterious effects for the children. In a marital search model, however, longer searches generally will lead to better matches. The ultimate effect of higher benefits on the child's lifetime exposure to fatherlessness therefore could be ambiguous. 


\section{References}

Bane, May Jo, and David T. Ellwood. "The Dynamics of Dependence: The Routes to self-sufficiency." Report to Assistant Secretary for Planning and Evaluation, U.S. Department of Health and Human Services, June 1983.

Bronars, Stephen G., and Jeff Grogger. "The Economic Consequences of Unwed Motherhood: Using Twins as a Natural Experiment." American Economic Review, December 1994, 1141-1156.

Devine, Theresa J., and Nicholas M. Kiefer. Empirical Labor Economics: The Search Approach. New York: Oxford University Press, 1991.

Ellwood, David T., and Mary Jo Bane. "The Impact of AFDC on Family Structure and Living Arrangements." Research in Labor Economics 7, 1985, 137-207.

Ermisch, John. Lone Parenthood: An Economic Analysis. New York: Cambridge University Press, 1991.

Grogger, Jeff, and Nick Ronan. "The Intergenerational Effects of Fatherlessness on Educational Attainment and Entry-Level Wages." Mimeo, Department of Economics, UC Santa Barbara, July 1995.

Heckman, James J. "The Incidental Parameters Problem and the Problem of Initial Conditions in Estimating and Discrete-Time, Discrete-Data Stochastic Process." In C.F. Manski and D. McFadden, eds., Structural Analysis of Discrete Data with Econometric Applications. Cambridge: MIT Press, 1981, 179-195.

Hoynes, Hilary. "Does Welfare Play Any Role in Female Headship Decisions?" Mimeo, Department of Economics, UC Berkeley, February 1995.

Jackson, Catherine, and Jacob Klerman. "Welfare and American Fertility." Mimeo, Rand Corporation, 1995.

Kiefer, J., and J. Wolfowitz. "Consistency of the Maximum Likelihood Estimator in the Presence of Infinitely Many Incidental Parameters." Annals of Mathematical Statistics 27, 1956, 887-906.

Kiefer, Nicholas M. "Analysis of Grouped Duration Data." Contemporary Mathematics $80,1988,107-137$.

Lundberg, Shelly, and Robert Plotnick. "Effects of State Welfare, Abortion, and Family Planning Policies on Premarital Childbearing Among White Adolescents." Family Planning Perspectives 22, 1990, 246-251. 
,"Adolescent Premarital Childbearing: Do Economic Incentives Matter?" Journal of Labor Economics 13, April 1995, 177-200.

Mittler, Peter. The Study of Twins. New York: Penguin Press, 1971.

Moffitt, Robert. "Incentive Effects of the U.S. Welfare System: A Review." Journal of Economic Literature 30, March 1992, 1-61.

, "Welfare Effects on Female Headship with Area Effects." Journal of Human Resources 29, Spring 1994, 621-636.

, "The Effect of the Welfare System on Nonmarital Childbearing." In Report to Congress on Out-of-Wedlock Childbearing, U.S. Department of Health and Human Services, September 1995, 167-176.

Moore, Kristen. "Executive Summary: Nonmarital Childbearing in the United States." In Report to Congress on Out-of-Wedlock Childbearing, U.S. Department of Health and Human Services, September 1995, v-xxii.

, and S. Caldwell. "The Effect of Government Policies on Out-of-Wedlock Sex and Pregnancy." Family Planning Perspectives 9, 1977, 164-169.

, Donna Ruane Morrison, Connie Blumenthal, Margaret L. Daly, and Rachel Bennett. "Data on Teenage Childbearing in the United States." Mimeo, Child Trends, Inc., January 1993.

Murray, Charles. Losing Ground. New York: Basic Books, 1984.

Plotnick, Robert. "Turnover in the AFDC Population: An Event History Analysis." Journal of Human Resources 18, 1983, 65-81.

Robins, Philip K., and Paul Fronstin. "Welfare Benefits and Family-Size Decisions of Never-Married Women." Institute for Research on Poverty Discussion Paper 1022-93, University of Wisconsin, September 1993.

Rosenzweig, Mark R., and Kenneth I. Wolpin. "Life-Cycle Labor Supply and Fertility: Causal Inference from Household Models." Journal of Political Economy 88, April 1980, 328-48.

Schultz, T. Paul. "Marital Status and Fertility in the United States." Journal of Human Resources 29, Spring 1994, 637-669. 
Sueyoshi, Glenn T. "Semiparametric Estimation of Generalized Accelerated Failure time Models with Grouped Data." Mimeo, Department of Economics, UC San Diego, undated.

U.S. Department of Health, Education, and Welfare, NCSS Report D-2, "OAA and AFDC: Cost Standards for Basic Needs and percent of Such Standards Met for Specific Types of Cases." Various years.

U.S. Department of Health, Education, and Welfare, NCSS Report D-3, "State Maximums and Other Methods of Limiting Money Payments to the Special Types of Public Assistance." Various years. 
Table 1

Summary Statistics, Whites

\begin{tabular}{|c|c|c|c|c|c|}
\hline \multicolumn{6}{|c|}{ A. Sample Characteristics and Background Variables } \\
\hline \multirow[b]{3}{*}{ Variable } & \multirow[b]{3}{*}{ Full sample } & \multicolumn{4}{|c|}{ Estimation samples } \\
\hline & & \multicolumn{2}{|c|}{$\begin{array}{c}\text { Benefits defined by } \\
\text { state of residence, } 1980\end{array}$} & \multicolumn{2}{|c|}{$\begin{array}{l}\text { Benefits defined by } \\
\text { state of child's birth }\end{array}$} \\
\hline & & Marriage & Births & Marriage & Births \\
\hline $\begin{array}{l}\text { Number of unwed } \\
\text { mothers }\end{array}$ & 44,037 & 16,004 & $15, \overline{420}$ & $15, \overline{730}$ & $15, \overline{143}$ \\
\hline $\begin{array}{l}\text { Number of } \\
\text { state/maternity } \\
\text { cohorts }\end{array}$ & 454 & 126 & 115 & 124 & 112 \\
\hline Number of states & 51 & 39 & 38 & 41 & 39 \\
\hline \multicolumn{5}{|l|}{ Distribution by } & \\
\hline Northeast & 17.5 & 13.6 & 13.7 & 14.3 & 14.3 \\
\hline Midwest & 29.8 & 21.9 & 21.3 & 23.9 & 23.3 \\
\hline South & 28.5 & 26.1 & 25.7 & 21.5 & 20.5 \\
\hline West & 24.3 & 38.4 & 39.4 & 40.3 & 41.8 \\
\hline $\begin{array}{l}\text { Mean benefit, } \\
\text { AFDC+FS, family } \\
\text { of } 2,1980\end{array}$ & $\begin{array}{l}319 \\
(67)\end{array}$ & $\begin{array}{l}317 \\
(73)\end{array}$ & $\begin{array}{l}316 \\
(70)\end{array}$ & $\begin{array}{l}320 \\
(75)\end{array}$ & $\begin{array}{l}320 \\
(73)\end{array}$ \\
\hline $\begin{array}{l}\text { Base benefit for } \\
\text { estimation sample, } \\
\text { AFDC+FS }\end{array}$ & & $\begin{array}{l}372 \\
(71)\end{array}$ & $\begin{array}{l}369 \\
(73)\end{array}$ & $\begin{array}{l}378 \\
(68)\end{array}$ & $\begin{array}{l}376 \\
(69)\end{array}$ \\
\hline $\begin{array}{l}\text { Marginal benefit } \\
\text { for estimation } \\
\text { sample, } \\
\text { AFDC+FS }\end{array}$ & & & $\begin{array}{l}116 \\
(16)\end{array}$ & & $\begin{array}{l}117 \\
(16)\end{array}$ \\
\hline $\begin{array}{l}\text { Mean age at } 1 \text { st } \\
\text { birth }\end{array}$ & $\begin{array}{c}80.4 \\
(15.1)\end{array}$ & $\begin{array}{c}80.8 \\
(15.7)\end{array}$ & $\begin{array}{c}80.9 \\
(15.8)\end{array}$ & $\begin{array}{c}80.7 \\
(15.4)\end{array}$ & $\begin{array}{c}80.8 \\
(15.4)\end{array}$ \\
\hline Percent twin births & 0.77 & 1.42 & 1.36 & 1.41 & 1.34 \\
\hline
\end{tabular}


Table 1 (con't.)

\section{B. Marital and Birth Outcomes}

\begin{tabular}{|c|c|c|c|c|c|}
\hline \multirow[b]{3}{*}{ Variable } & \multirow[b]{3}{*}{ Full sample } & \multicolumn{4}{|c|}{ Estimation samples } \\
\hline & & \multicolumn{2}{|c|}{$\begin{array}{c}\text { Benefits defined by } \\
\text { state of residence, } 1980\end{array}$} & \multicolumn{2}{|c|}{$\begin{array}{l}\text { Benefits defined by } \\
\text { state of child's birth }\end{array}$} \\
\hline & & Marriage & Births & Marriage & Births \\
\hline $\begin{array}{l}\text { Percent ever } \\
\text { marrying }\end{array}$ & 69.7 & 64.0 & & 62.3 & \\
\hline $\begin{array}{l}\text { Mean time to Ist } \\
\text { marriage, } \\
\text { completed spells }\end{array}$ & $\begin{array}{c}9.5 \\
(9.5)\end{array}$ & $\begin{array}{c}8.3 \\
(8.4)\end{array}$ & & $\begin{array}{c}7.9 \\
(8.2)\end{array}$ & \\
\hline $\begin{array}{l}\text { Mean time to 1st } \\
\text { marriage, } \\
\text { censored spells }\end{array}$ & $\begin{array}{c}17.1 \\
(13.5)\end{array}$ & $\begin{array}{c}14.1 \\
(10.7)\end{array}$ & & $\begin{array}{l}13.7 \\
(10.4)\end{array}$ & \\
\hline $\begin{array}{l}\text { Mean time to lst } \\
\text { marriage, } \\
\text { unconditional }^{\mathrm{a}}\end{array}$ & 16.9 & 16.2 & & 16.2 & \\
\hline $\begin{array}{l}\text { Median time to } \\
1 \text { st marriage, } \\
\text { unconditional }\end{array}$ & 11.0 & 11.0 & & 11.0 & \\
\hline $\begin{array}{l}\text { Percent having } \\
\text { subsequent birth }\end{array}$ & 51.7 & & 44.9 & & 43.3 \\
\hline $\begin{array}{l}\text { Mean time to 2nd } \\
\text { birth, completed } \\
\text { spells }\end{array}$ & $\begin{array}{l}13.5 \\
(7.9)\end{array}$ & & $\begin{array}{l}12.5 \\
(7.3)\end{array}$ & & $\begin{array}{l}12.2 \\
(7.1)\end{array}$ \\
\hline $\begin{array}{l}\text { Mean time to 2nd } \\
\text { birth, censored } \\
\text { spells }\end{array}$ & $\begin{array}{c}19.5 \\
(14.2)\end{array}$ & & $\begin{array}{c}16.7 \\
(11.7)\end{array}$ & & $\begin{array}{l}16.0 \\
(11.4)\end{array}$ \\
\hline $\begin{array}{l}\text { Mean time to 2nd } \\
\text { birth, } \\
\text { unconditional } \mathrm{l}^{\mathrm{a}}\end{array}$ & 31.7 & & 33.0 & & 33.1 \\
\hline $\begin{array}{l}\text { Median time to } \\
\text { 2nd birth, } \\
\text { unconditional }\end{array}$ & 19.0 & & 20.0 & & 20.0 \\
\hline
\end{tabular}

a - Assumes that spells are exponentially distributed.

Notes: All durations and ages are measured in calendar quarters. Standard deviations are in parentheses. 
Table 2

Summary Statistics, Blacks

\begin{tabular}{|c|c|c|c|c|c|}
\hline \multicolumn{5}{|c|}{ A. Sample Characteristics and Background Variables } & \\
\hline \multirow[b]{2}{*}{ Variable } & \multirow[b]{2}{*}{ Full sample } & \multicolumn{2}{|c|}{$\begin{array}{c}\text { Benefits defined by } \\
\text { state of residence. } 1980\end{array}$} & \multicolumn{2}{|c|}{$\begin{array}{l}\text { Benefits defined by } \\
\text { state of child's birth }\end{array}$} \\
\hline & & Marriage & Births & Marriage & Births \\
\hline $\begin{array}{l}\text { Number of unwed } \\
\text { mothers }\end{array}$ & 45,746 & 21,057 & 20,999 & 20,559 & 20,491 \\
\hline $\begin{array}{l}\text { Number of } \\
\text { state/maternity } \\
\text { cohorts }\end{array}$ & 222 & 143 & 141 & 144 & 142 \\
\hline Number of states & 50 & 28 & 29 & 29 & 29 \\
\hline \multicolumn{6}{|l|}{ Distribution by } \\
\hline Northeast & 17.8 & 16.7 & 16.6 & 17.1 & 17.0 \\
\hline Midwest & 24.3 & 19.3 & 19.5 & 20.4 & 20.4 \\
\hline South & 49.1 & 53.1 & 53.1 & 52.6 & 52.7 \\
\hline West & 8.8 & 10.8 & 10.8 & 9.9 & 9.9 \\
\hline $\begin{array}{l}\text { Mean benefit, } \\
\text { AFDC+FS, family } \\
\text { of } 2,1980\end{array}$ & $\begin{array}{l}319 \\
(68)\end{array}$ & $\begin{array}{l}303 \\
(90)\end{array}$ & $\begin{array}{l}307 \\
(91)\end{array}$ & $\begin{array}{l}303 \\
(82)\end{array}$ & $\begin{array}{l}303 \\
(82)\end{array}$ \\
\hline $\begin{array}{l}\text { Base benefit for } \\
\text { estimation sample, } \\
\text { AFDC+FS }\end{array}$ & & $\begin{array}{l}332 \\
(78)\end{array}$ & $\begin{array}{l}334 \\
(78)\end{array}$ & $\begin{array}{l}328 \\
(80)\end{array}$ & $\begin{array}{l}330 \\
(80)\end{array}$ \\
\hline $\begin{array}{l}\text { Marginal benefit } \\
\text { for estimation } \\
\text { sample, } \\
\text { AFDC+FS }\end{array}$ & & & $\begin{array}{l}110 \\
(18)\end{array}$ & & $\begin{array}{l}109 \\
(18)\end{array}$ \\
\hline $\begin{array}{l}\text { Mean age at } 1 \mathrm{st} \\
\text { birth }\end{array}$ & $\begin{array}{c}76.7 \\
(14.0)\end{array}$ & $\begin{array}{c}77.3 \\
(14.2)\end{array}$ & $\begin{array}{c}77.3 \\
(14.2)\end{array}$ & $\begin{array}{c}77.2 \\
(14.2)\end{array}$ & $\begin{array}{c}77.2 \\
(14.2)\end{array}$ \\
\hline Percent twin births & 1.00 & 1.38 & 1.36 & 1.43 & 1.42 \\
\hline
\end{tabular}


Table 2 (con't.)

\section{B. Marital and Birth Outcomes}

\begin{tabular}{|c|c|c|c|c|c|}
\hline \multirow[b]{3}{*}{ Variable } & \multirow[b]{3}{*}{ Full sample } & \multicolumn{4}{|c|}{ Estimation samples } \\
\hline & & \multicolumn{2}{|c|}{$\begin{array}{c}\text { Benefits defined by } \\
\text { state of residence. } 1980\end{array}$} & \multicolumn{2}{|c|}{$\begin{array}{l}\text { Benefits defined by } \\
\text { state of child's birth }\end{array}$} \\
\hline & & Marriage & Births & Marriage & Births \\
\hline $\begin{array}{l}\text { Percent ever } \\
\text { marrying }\end{array}$ & 39.5 & 32.1 & & 31.6 & \\
\hline $\begin{array}{l}\text { Mean time to Ist } \\
\text { marriage, } \\
\text { completed spelts }\end{array}$ & $\begin{array}{l}11.7 \\
(10.0)\end{array}$ & $\begin{array}{l}10.2 \\
(8.7)\end{array}$ & & $\begin{array}{l}10.2 \\
(8.9)\end{array}$ & \\
\hline $\begin{array}{l}\text { Mean time to } 1 \text { st } \\
\text { marriage, } \\
\text { censored spells }\end{array}$ & $\begin{array}{l}21.7 \\
(13.9)\end{array}$ & $\begin{array}{l}16.6 \\
(11.1)\end{array}$ & & $\begin{array}{c}16.6 \\
(11.2)\end{array}$ & \\
\hline $\begin{array}{l}\text { Mean time to } 1 \mathrm{st} \\
\text { marriage, } \\
\text { unconditional }^{\mathrm{a}}\end{array}$ & 45.0 & 45.2 & & 46.0 & \\
\hline $\begin{array}{l}\text { Median time to } \\
\text { 1 st marriage, } \\
\text { unconditional }\end{array}$ & 34.0 & 35.0 & & 35.0 & \\
\hline $\begin{array}{l}\text { Percent having } \\
\text { subsequent birth }\end{array}$ & 50.0 & & 41.5 & & 42.0 \\
\hline $\begin{array}{l}\text { Mean time to 2nd } \\
\text { birth, completed } \\
\text { spells }\end{array}$ & $\begin{array}{l}12.9 \\
(8.3)\end{array}$ & & $\begin{array}{l}11.6 \\
(7.2)\end{array}$ & ${ }^{\circ}$ & $\begin{array}{l}11.6 \\
(7.3)\end{array}$ \\
\hline $\begin{array}{l}\text { Mean time to 2nd } \\
\text { birth, censored } \\
\text { spells }\end{array}$ & $\begin{array}{c}19.3 \\
(13.7)\end{array}$ & & $\begin{array}{c}15.1 \\
(10.6)\end{array}$ & & $\begin{array}{c}14.9 \\
(10.6)\end{array}$ \\
\hline $\begin{array}{l}\text { Mean time to 2nd } \\
\text { birth, } \\
\text { unconditional }^{\mathrm{a}}\end{array}$ & 31.0 & & 32.9 & & 32.3 \\
\hline $\begin{array}{l}\text { Median time to } \\
2 \text { nd birth, } \\
\text { unconditional }\end{array}$ & 19.0 & & 20.0 & & 20.0 \\
\hline
\end{tabular}

${ }^{\mathrm{a}}$ - Assumes that spells are exponentially distributed.

Notes: All durations and ages are measured in calendar quarters. Standard deviations are in parentheses. 
Table 3

Estimates of Logistic Discrete-Time Hazard Models for Time-to-First-Marriage and Time-to-NextBirth among Initially Unwed Mothers, Without State/Maternity Cohort Dummies

\begin{tabular}{|c|c|c|c|c|}
\hline \multicolumn{5}{|c|}{ A. Time-to-First-Marriage } \\
\hline \multirow[b]{2}{*}{$\begin{array}{l}\text { Definition of } \\
\text { benefits: } \\
\text { Variable }\end{array}$} & \multicolumn{2}{|c|}{ Whites } & \multicolumn{2}{|c|}{ Blacks } \\
\hline & $\begin{array}{l}\text { State of residence } \\
\text { in } 1980 \\
\text { (1) }\end{array}$ & $\begin{array}{l}\text { State of child's } \\
\text { birth } \\
\text { (2) }\end{array}$ & $\begin{array}{l}\text { State of residence } \\
\text { in } 1980\end{array}$ & $\begin{array}{c}\text { State of child's } \\
\text { birth }\end{array}$ \\
\hline Base benefit, & -0.0016 & -0.0014 & -0.0018 & $\frac{1}{-0.0018}$ \\
\hline $\mathrm{AFDC}+\mathrm{FS}$ & $(0.0001)$ & $(0.0002)$ & $(0.0002)$ & $(0.0002)$ \\
\hline Twin dummy & 0.3360 & 0.3114 & 0.1699 & 0.1785 \\
\hline & $(0.0881)$ & $(0.0893)$ & $(0.1081)$ & $(0.1071)$ \\
\hline Log likelihood & $-37,634.7$ & $-35,986.8$ & $-32,047.8$ & $-30,959.5$ \\
\hline $\begin{array}{l}\text { Number of } \\
\text { mothers }\end{array}$ & 16,004 & 15,730 & 21,057 & 20,559 \\
\hline $\begin{array}{l}\text { Number of } \\
\text { observations }\end{array}$ & 166,012 & 158,929 & 305,398 & 299,183 \\
\hline \multicolumn{5}{|c|}{ B. Time-to-Next-Birth } \\
\hline & \multicolumn{2}{|c|}{ Whites } & \multicolumn{2}{|c|}{ Blacks } \\
\hline $\begin{array}{l}\text { Definition of } \\
\text { benefits: } \\
\text { Variable }\end{array}$ & $\begin{array}{l}\text { State of residence } \\
\text { in } 1980 \\
\text { (1) }\end{array}$ & $\begin{array}{l}\text { State of child's } \\
\text { birth } \\
\text { (2) }\end{array}$ & $\begin{array}{c}\text { State of residence } \\
\text { in } 1980 \\
\text { (3) }\end{array}$ & $\begin{array}{l}\text { State of child's } \\
\text { birth } \\
\text { (4) }\end{array}$ \\
\hline $\begin{array}{l}\text { Base benefit, } \\
\text { AFDC + FS }\end{array}$ & $\begin{array}{c}0.0001 \\
(0.0003)\end{array}$ & $\begin{array}{l}-0.0005 \\
(0.0003)\end{array}$ & $\begin{array}{l}-0.0011 \\
(0.0003)\end{array}$ & $\begin{array}{c}-0.0011 \\
(0.0003)\end{array}$ \\
\hline $\begin{array}{l}\text { Marginal benefit, } \\
\text { AFDC+FS }\end{array}$ & $\begin{array}{l}-0.0003 \\
(0.0015)\end{array}$ & $\begin{array}{c}0.0014 \\
(0.0016)\end{array}$ & $\begin{array}{c}0.0006 \\
(0.0011)\end{array}$ & $\begin{array}{c}0.0005 \\
(0.0011)\end{array}$ \\
\hline Twin dummy & $\begin{array}{l}-0.3684 \\
(0.1315)\end{array}$ & $\begin{array}{c}-0.2874 \\
(0.1341)\end{array}$ & $\begin{array}{l}-0.1180 \\
(0.1119)\end{array}$ & $\begin{array}{l}-0.1251 \\
(0.1094)\end{array}$ \\
\hline Log likelihood & $-29,474.8$ & $-27,901.5$ & $-37,398.7$ & $-36,723.1$ \\
\hline $\begin{array}{l}\text { Number of } \\
\text { mothers }\end{array}$ & 15,420 & 15,143 & 20,999 & 20,491 \\
\hline $\begin{array}{l}\text { Number of } \\
\text { observations }\end{array}$ & 228,552 & 217,158 & 286,703 & 277,461 \\
\hline
\end{tabular}

Notes: Standard errors are in parentheses. In addition the variables shown, all models include the mother's age at her first birth, a calendar time trend, and a full set of dummies for elapsed duration. 
Table 4

Twins Estimates of Logistic Discrete-Time Hazard Models for Time-to-First-Marriage and Time-to-Next-Birth among Initially Unwed Mothers

\begin{tabular}{|c|c|c|c|c|}
\hline \multicolumn{5}{|c|}{ A. Time-to-First-Marriage } \\
\hline \multirow[b]{2}{*}{$\begin{array}{l}\text { Definition of } \\
\text { benefits: } \\
\text { Variable }\end{array}$} & \multicolumn{2}{|c|}{ Whites } & \multicolumn{2}{|c|}{ Blacks } \\
\hline & $\begin{array}{l}\text { State of residence } \\
\text { in } 1980 \\
\text { (1) }\end{array}$ & $\begin{array}{l}\text { State of child's } \\
\text { birth } \\
\text { (2) }\end{array}$ & $\begin{array}{l}\text { State of residence } \\
\text { in } 1980 \\
\text { (3) }\end{array}$ & $\begin{array}{c}\text { State of child's } \\
\text { birth } \\
\text { (4) }\end{array}$ \\
\hline $\begin{array}{l}\text { Base benefit, } \\
\text { AFDC + FS }\end{array}$ & $\begin{array}{c}-0.0019 \\
(0.0006)\end{array}$ & $\begin{array}{l}-0.00 \overline{18} \\
(0.0006)\end{array}$ & $\begin{array}{c}0.0003 \\
(0.0008)\end{array}$ & $\begin{array}{l}-0.0000 \\
(0.0008)\end{array}$ \\
\hline Twin dummy & $\begin{array}{c}0.3702 \\
(0.1083)\end{array}$ & $\begin{array}{c}0.3677 \\
(0.1102)\end{array}$ & $\begin{array}{l}-0.0281 \\
(0.1401)\end{array}$ & $\begin{array}{c}0.0050 \\
(0.1376)\end{array}$ \\
\hline Log likelihood & $-37,527.3$ & $-35,879.2$ & $-31,863.4$ & $-30,795.6$ \\
\hline $\begin{array}{l}\text { Number of } \\
\text { mothers }\end{array}$ & 16,004 & 15,370 & 21,057 & 20,559 \\
\hline $\begin{array}{l}\text { Number of } \\
\text { observations }\end{array}$ & 166,012 & 158,929 & 305,398 & 299,183 \\
\hline \multicolumn{5}{|c|}{ B. Time-to-Next-Birth } \\
\hline & \multicolumn{2}{|c|}{$\begin{array}{l}\text { Whites } \\
\end{array}$} & \multicolumn{2}{|c|}{ Blacks } \\
\hline $\begin{array}{l}\text { Definition of } \\
\text { benefits: } \\
\text { Variable }\end{array}$ & $\begin{array}{l}\text { State of residence } \\
\text { in } 1980 \\
\text { (1) }\end{array}$ & $\begin{array}{l}\text { State of child's } \\
\text { birth } \\
\text { (2) }\end{array}$ & $\begin{array}{l}\text { State of residence } \\
\text { in } 1980 \\
\text { (3) }\end{array}$ & $\begin{array}{l}\text { State of child's } \\
\text { birth } \\
\text { (4) }\end{array}$ \\
\hline $\begin{array}{l}\text { Base benefit, } \\
\text { AFDC + FS }\end{array}$ & $\begin{array}{c}0.0011 \\
(0.0013)\end{array}$ & $\begin{array}{l}-0.0005 \\
(0.0013)\end{array}$ & $\begin{array}{c}0.0020 \\
(0.0010)\end{array}$ & $\begin{array}{c}0.0018 \\
(0.0010)\end{array}$ \\
\hline $\begin{array}{l}\text { Marginal benefit, } \\
\text { AFDC+FS }\end{array}$ & $\begin{array}{l}-0.0028 \\
(0.0032)\end{array}$ & $\begin{array}{c}0.0015 \\
(0.0032)\end{array}$ & $\begin{array}{c}0.0029 \\
(0.0024)\end{array}$ & $\begin{array}{c}0.0004 \\
(0.0024)\end{array}$ \\
\hline Twin dummy & $\begin{array}{l}-0.5095 \\
(0.2101)\end{array}$ & $\begin{array}{l}-0.2859 \\
(0.2102)\end{array}$ & $\begin{array}{l}-0.4203 \\
(0.1653)\end{array}$ & $\begin{array}{l}-0.4125 \\
(0.1611)\end{array}$ \\
\hline Log likelihood & $-29,394.5$ & $-27,817.9$ & $-37,247.5$ & $-36,577.6$ \\
\hline $\begin{array}{l}\text { Number of } \\
\text { mothers }\end{array}$ & 15,420 & 15,413 & 20,999 & 20,491 \\
\hline $\begin{array}{l}\text { Number of } \\
\text { observations }\end{array}$ & 228,552 & 217,158 & 286,703 & 277,461 \\
\hline
\end{tabular}

Notes: Standard errors are in parentheses. In addition the variables shown, all models include the mother's age at her first birth, a calendar time trend, the state/maternity cohort dummies, and a full set of dummies for elapsed duration. 
Table 5

Additional Twins Estimates of Logistic Discrete-Time Hazard Models for Time-to-First-Marriage and Time-to-Next-Birth among Initially Unwed White Mothers

\begin{tabular}{|c|c|c|c|c|c|c|}
\hline \multirow{2}{*}{$\begin{array}{l}\text { A. Time-to First-Ma } \\
\text { Definition of } \\
\text { benefits: } \\
\text { Variable }\end{array}$} & \multicolumn{3}{|c|}{ State of residence in 1980} & \multicolumn{3}{|c|}{ State of child's birth } \\
\hline & $(1)$ & $(2)$ & (3) & (4) & $(5)$ & $(6)$ \\
\hline $\begin{array}{l}\text { Base benefit, } \\
\text { AFDC + FS }\end{array}$ & $\begin{array}{l}-0.0019 \\
(0.0006)\end{array}$ & $\begin{array}{l}-0.0019 \\
(0.0006)\end{array}$ & $\begin{array}{l}-0.0019 \\
(0.0006)\end{array}$ & $\begin{array}{l}-0.0017 \\
(0.0006)\end{array}$ & $\begin{array}{l}-0.0018 \\
(0.0006)\end{array}$ & $\begin{array}{l}-0.0017 \\
(0.0006)\end{array}$ \\
\hline $\begin{array}{l}\text { Base benefit } x \text { twin } \\
\text { dummy }\end{array}$ & & & $\begin{array}{l}-0.0003 \\
(0.0010)\end{array}$ & & & $\begin{array}{l}-0.0004 \\
(0.0010)\end{array}$ \\
\hline Twin dummy & $\begin{array}{c}0.1265 \\
(0.1769)\end{array}$ & $\begin{array}{l}-0.7228 \\
(2.2655)\end{array}$ & $\begin{array}{c}0.5223 \\
(0.4625)\end{array}$ & $\begin{array}{c}0.2242 \\
(0.1817)\end{array}$ & $\begin{array}{l}-0.2795 \\
(2.3621)\end{array}$ & $\begin{array}{c}0.5626 \\
(0.4754)\end{array}$ \\
\hline $\begin{array}{l}\text { Northeast region } \mathrm{x} \\
\text { twin dummy }\end{array}$ & $\begin{array}{c}0.3797 \\
(0.2982)\end{array}$ & & & $\begin{array}{c}0.1980 \\
(0.3010)\end{array}$ & & \\
\hline $\begin{array}{l}\text { Midwest region } \mathrm{x} \\
\text { twin dummy }\end{array}$ & $\begin{array}{c}0.3450 \\
(0.2467)\end{array}$ & & & $\begin{array}{c}0.1018 \\
(0.2432)\end{array}$ & & \\
\hline $\begin{array}{l}\text { South region } \mathrm{x} \text { twin } \\
\text { dummy }\end{array}$ & $\begin{array}{c}0.3472 \\
(0.2197)\end{array}$ & & & $\begin{array}{c}0.2768 \\
(0.2286)\end{array}$ & & \\
\hline $\begin{array}{l}\text { Calendar year } \mathrm{x} \\
\text { twin dummy }\end{array}$ & & $\begin{array}{l}-0.0046 \\
(0.0298)\end{array}$ & & & $\begin{array}{c}0.0085 \\
(0.0311)\end{array}$ & \\
\hline $\begin{array}{l}\chi_{3}^{2} \text { for twin- } \\
\text { region interactions }\end{array}$ & $\begin{array}{c}3.32 \\
{[0.34]}\end{array}$ & & & $\begin{array}{c}1.57 \\
{[0.67]}\end{array}$ & & \\
\hline Log likelihood & $-37,525.6$ & $-37,527.3$ & $-37,527.2$ & $-35,878.4$ & $-35,879.1$ & $-35,879.1$ \\
\hline $\begin{array}{l}\text { Number of } \\
\text { observations }\end{array}$ & 166,012 & 166,012 & 166,012 & 158,929 & 158,929 & 158,929 \\
\hline
\end{tabular}


Table 5 (con't.)

\begin{tabular}{|c|c|c|c|c|c|c|}
\hline \multirow{2}{*}{$\begin{array}{l}\text { B. Time-to-Next-Bi } \\
\text { Definition of } \\
\text { benefits: } \\
\text { Variable }\end{array}$} & \multicolumn{3}{|c|}{ State of residence in 1980} & \multicolumn{3}{|c|}{ State of child's birth } \\
\hline & (1) & $(2)$ & (3) & (4) & $(5)$ & $(6)$ \\
\hline $\begin{array}{l}\text { Base benefit, } \\
\text { AFDC + FS }\end{array}$ & $\begin{array}{c}0.0013 \\
(0.0013)\end{array}$ & $\begin{array}{c}0.0011 \\
(0.0013)\end{array}$ & $\begin{array}{c}0.0011 \\
(0.0014)\end{array}$ & $\begin{array}{l}-0.0003 \\
(0.0013)\end{array}$ & $\begin{array}{l}-0.0005 \\
(0.0013)\end{array}$ & $\begin{array}{l}-0.0003 \\
(0.0014)\end{array}$ \\
\hline $\begin{array}{l}\text { Base benefit } x \text { twin } \\
\text { dummy }\end{array}$ & & & $\begin{array}{l}-0.0001 \\
(0.0028)\end{array}$ & & & $\begin{array}{l}-0.0016 \\
(0.0028)\end{array}$ \\
\hline $\begin{array}{l}\text { Marginal benefit, } \\
\text { AFDC+FS }\end{array}$ & $\begin{array}{l}-0.0030 \\
(0.0032)\end{array}$ & $\begin{array}{l}-0.0027 \\
(0.0032)\end{array}$ & $\begin{array}{l}-0.0027 \\
(0.0033)\end{array}$ & $\begin{array}{c}0.0012 \\
(0.0032)\end{array}$ & $\begin{array}{c}0.0015 \\
(0.0032)\end{array}$ & $\begin{array}{c}0.0011 \\
(0.0033)\end{array}$ \\
\hline $\begin{array}{l}\text { Marginal benefit } x \\
\text { twin dummy }\end{array}$ & & & $\begin{array}{l}-0.0026 \\
(0.0126)\end{array}$ & & & $\begin{array}{c}0.0034 \\
(0.0126)\end{array}$ \\
\hline Twin dummy & $\begin{array}{l}-0.8407 \\
(0.2996)\end{array}$ & $\begin{array}{l}-2.2451 \\
(3.6336)\end{array}$ & $\begin{array}{l}-0.1813 \\
(0.6796)\end{array}$ & $\begin{array}{l}-0.4270 \\
(0.2994)\end{array}$ & $\begin{array}{l}-2.1467 \\
(3.8319)\end{array}$ & $\begin{array}{c}0.0564 \\
(0.7153)\end{array}$ \\
\hline $\begin{array}{l}\text { Northeast region } \mathrm{x} \\
\text { twin dummy }\end{array}$ & $\begin{array}{c}0.0929 \\
(0.4539)\end{array}$ & & & $\begin{array}{l}-0.2043 \\
(0.4546)\end{array}$ & & \\
\hline $\begin{array}{l}\text { Midwest region } x \\
\text { twin dummy }\end{array}$ & $\begin{array}{c}0.7192 \\
(0.3352)\end{array}$ & & & $\begin{array}{c}0.3292 \\
(0.3304)\end{array}$ & & \\
\hline $\begin{array}{l}\text { South region } \mathrm{x} \text { twin } \\
\text { dummy }\end{array}$ & $\begin{array}{c}0.3907 \\
(0.3226)\end{array}$ & & & $\begin{array}{c}0.1904 \\
(0.3337)\end{array}$ & & \\
\hline $\begin{array}{l}\text { Calendar year } x \\
\text { twin dummy }\end{array}$ & & $\begin{array}{c}0.0228 \\
(0.0475)\end{array}$ & & & $\begin{array}{c}0.0243 \\
(0.0500)\end{array}$ & \\
\hline $\begin{array}{l}\chi_{3}^{2} \text { for twin- } \\
\text { region interactions }\end{array}$ & $\begin{array}{c}5.09 \\
{[0.17]}\end{array}$ & & & $\begin{array}{c}1.87 \\
{[0.60]}\end{array}$ & & \\
\hline Log likelihood & $-29,392.0$ & $-29,394.4$ & $-29,394.4$ & $-27,817.0$ & $-27,817.8$ & $-27,817.7$ \\
\hline $\begin{array}{l}\text { Number of } \\
\text { observations }\end{array}$ & 228,552 & 228,552 & 228,552 & 217,158 & 217,158 & 217,158 \\
\hline
\end{tabular}

Notes: Standard errors are in parentheses; significance levels are in square brackets. In addition the variables shown, all models include the mother's age at her first birth, a calendar time trend, the state/maternity cohort dummies, and a full set of dummies for elapsed duration. 
Table 6

Additional Twins Estimates of Logistic Discrete-Time Hazard Models for Time-to-First-Marriage and Time-to-Next-Birth among Initially Unwed Black Mothers

\begin{tabular}{|c|c|c|c|c|c|c|}
\hline \multirow{2}{*}{$\begin{array}{l}\text { A. Time-to-First-Ma } \\
\text { Definition of } \\
\text { benefits: } \\
\text { Variable }\end{array}$} & \multicolumn{3}{|c|}{ State of residence in 1980} & \multicolumn{3}{|c|}{ State of child's birth } \\
\hline & (1) & $(2)$ & (3) & (4) & $(5)$ & (6) \\
\hline $\begin{array}{l}\text { Base benefit, } \\
\text { AFDC + FS }\end{array}$ & $\begin{array}{c}0.0003 \\
(0.0008)\end{array}$ & $\begin{array}{c}0.0003 \\
(0.0008)\end{array}$ & $\begin{array}{c}0.0002 \\
(0.0008)\end{array}$ & $\begin{array}{l}-0.0000 \\
(0.0008)\end{array}$ & $\begin{array}{l}-0.0000 \\
(0.0008)\end{array}$ & $\begin{array}{l}-0.0002 \\
(0.0008)\end{array}$ \\
\hline $\begin{array}{l}\text { Base benefit } x \text { twin } \\
\text { dummy }\end{array}$ & & & $\begin{array}{c}0.0029 \\
(0.0018)\end{array}$ & & & $\begin{array}{c}0.0025 \\
(0.0018)\end{array}$ \\
\hline Twin dummy & $\begin{array}{c}0.1460 \\
(0.3602)\end{array}$ & $\begin{array}{l}-1.5408 \\
(2.9523)\end{array}$ & $\begin{array}{l}-1.4191 \\
(1.0539)\end{array}$ & $\begin{array}{c}0.2366 \\
(0.3609)\end{array}$ & $\begin{array}{l}-0.4868 \\
(2.8595)\end{array}$ & $\begin{array}{l}-1.1267 \\
(1.0639)\end{array}$ \\
\hline $\begin{array}{l}\text { Northeast region } x \\
\text { twin dumny }\end{array}$ & $\begin{array}{c}0.0638 \\
(0.4715)\end{array}$ & $\begin{array}{c}0.0757 \\
(0.4719)\end{array}$ & $\begin{array}{c}0.0295 \\
(0.4722)\end{array}$ & $\begin{array}{l}-0.0001 \\
(0.4630)\end{array}$ & $\begin{array}{c}0.0052 \\
(0.4634)\end{array}$ & $\begin{array}{l}-0.0294 \\
(0.4638)\end{array}$ \\
\hline $\begin{array}{l}\text { Midwest region } x \\
\text { twin dummy }\end{array}$ & $\begin{array}{l}-1.2139 \\
(0.5362)\end{array}$ & $\begin{array}{l}-1.2014 \\
(0.5366)\end{array}$ & $\begin{array}{l}-0.9531 \\
(0.5591)\end{array}$ & $\begin{array}{l}-1.1769 \\
(0.5148)\end{array}$ & $\begin{array}{l}-1.1702 \\
(0.5154)\end{array}$ & $\begin{array}{l}-0.9415 \\
(0.5411)\end{array}$ \\
\hline $\begin{array}{l}\text { South region } x \text { twin } \\
\text { dummy }\end{array}$ & $\begin{array}{l}-0.0575 \\
(0.3667)\end{array}$ & $\begin{array}{l}-0.2072 \\
(0.3719)\end{array}$ & $\begin{array}{c}0.4335 \\
(0.4746)\end{array}$ & $\begin{array}{l}-0.1210 \\
(0.3685)\end{array}$ & $\begin{array}{l}-0.1056 \\
(0.3732)\end{array}$ & $\begin{array}{c}0.3150 \\
(0.4829)\end{array}$ \\
\hline $\begin{array}{l}\text { Calendar year } x \\
\text { twin dummy }\end{array}$ & & $\begin{array}{c}0.0219 \\
(0.0381)\end{array}$ & & & $\begin{array}{c}0.0094 \\
(0.0369)\end{array}$ & \\
\hline $\begin{array}{l}\chi_{3}^{2} \text { for twin- } \\
\text { region interactions }\end{array}$ & $\begin{array}{c}7.75 \\
{[0.05]}\end{array}$ & $\begin{array}{c}7.90 \\
{[0.05]}\end{array}$ & $\begin{array}{c}9.35 \\
{[0.03]}\end{array}$ & $\begin{array}{l}7.65 \\
{[0.05]}\end{array}$ & $\begin{array}{c}7.69 \\
{[0.05]}\end{array}$ & $\begin{array}{c}8.71 \\
{[0.03]}\end{array}$ \\
\hline Log likelihood & $-31,858.0$ & $-31,857.8$ & $-31,856.8$ & $-30,790.5$ & $-30,790.4$ & $-30,789.6$ \\
\hline $\begin{array}{l}\text { Number of } \\
\text { observations }\end{array}$ & 305,398 & 305,398 & 305,398 & 299,183 & 299,183 & 299,183 \\
\hline
\end{tabular}


Table 6 (con't.)

\begin{tabular}{|c|c|c|c|c|c|c|}
\hline \multirow[t]{2}{*}{$\begin{array}{l}\text { B. Time-to-Next-Bit } \\
\text { Definition of } \\
\text { benefits: } \\
\text { Variable }\end{array}$} & \multicolumn{3}{|c|}{ State of residence in 1980} & \multicolumn{3}{|c|}{ State of child's birth } \\
\hline & (1) & $(2)$ & (3) & (4) & (5) & $(6)$ \\
\hline $\begin{array}{l}\text { Base benefit, } \\
\text { AFDC + FS }\end{array}$ & $\begin{array}{c}0.0023 \\
(0.0010)\end{array}$ & $\begin{array}{c}0.0020 \\
(0.0010)\end{array}$ & $\begin{array}{c}0.0022 \\
(0.0010)\end{array}$ & $\begin{array}{c}0.0020 \\
(0.0010)\end{array}$ & $\begin{array}{c}0.0018 \\
(0.0010)\end{array}$ & $\begin{array}{c}0.0020 \\
(0.0010)\end{array}$ \\
\hline $\begin{array}{l}\text { Base benefit } x \text { twin } \\
\text { dummy }\end{array}$ & & & $\begin{array}{l}-0.0040 \\
(0.0027)\end{array}$ & & & $\begin{array}{l}-0.0031 \\
(0.0026)\end{array}$ \\
\hline $\begin{array}{l}\text { Marginal benefit, } \\
\text { AFDC+FS }\end{array}$ & $\begin{array}{c}0.0025 \\
(0.0025)\end{array}$ & $\begin{array}{c}0.0031 \\
(0.0025)\end{array}$ & $\begin{array}{c}0.0024 \\
(0.0025)\end{array}$ & $\begin{array}{c}0.0000 \\
(0.0024)\end{array}$ & $\begin{array}{c}0.0002 \\
(0.0024)\end{array}$ & $\begin{array}{l}-0.0000 \\
(0.0024)\end{array}$ \\
\hline $\begin{array}{l}\text { Marginal benefit } x \\
\text { twin dummy }\end{array}$ & & & $\begin{array}{c}0.0171 \\
(0.0127)\end{array}$ & & & $\begin{array}{c}0.0129 \\
(0.0123)\end{array}$ \\
\hline Twin dummy & $\begin{array}{l}-1.9058 \\
(0.7277)\end{array}$ & $\begin{array}{c}2.6788 \\
(2.9522)\end{array}$ & $\begin{array}{l}-0.4102 \\
(0.5866)\end{array}$ & $\begin{array}{l}-1.8620 \\
(0.7282)\end{array}$ & $\begin{array}{c}2.1085 \\
(2.8468)\end{array}$ & $\begin{array}{l}-0.3908 \\
(0.5602)\end{array}$ \\
\hline $\begin{array}{l}\text { Northeast region } x \\
\text { twin dummy }\end{array}$ & $\begin{array}{c}1.1003 \\
(0.7986)\end{array}$ & & & $\begin{array}{c}1.2658 \\
(0.7839)\end{array}$ & & \\
\hline $\begin{array}{l}\text { Midwest region } \mathrm{x} \\
\text { twin dummy }\end{array}$ & $\begin{array}{c}1.6103 \\
(0.7483)\end{array}$ & & & $\begin{array}{c}1.6555 \\
(0.7468)\end{array}$ & & \\
\hline $\begin{array}{l}\text { South region } \mathrm{x} \text { twin } \\
\text { dummy }\end{array}$ & $\begin{array}{c}1.5682 \\
(0.7252)\end{array}$ & & & $\begin{array}{c}1.4755 \\
(0.7263)\end{array}$ & & \\
\hline $\begin{array}{l}\text { Calendar year } x \\
\text { twin dummy }\end{array}$ & & $\begin{array}{l}-0.0407 \\
(0.0388)\end{array}$ & & & $\begin{array}{l}-0.0332 \\
(0.0375)\end{array}$ & \\
\hline $\begin{array}{l}\chi_{3}^{2} \text { for twin- } \\
\text { region interactions }\end{array}$ & $\begin{array}{c}6.14 \\
{[0.10]}\end{array}$ & & & $\begin{array}{c}5.35 \\
{[0.15]}\end{array}$ & & \\
\hline Log likelihood & $-37,242.9$ & $-37,247.0$ & $-37,246.3$ & $-36,573.6$ & $-36,577.2$ & $-36,576.9$ \\
\hline $\begin{array}{l}\text { Number of } \\
\text { observations }\end{array}$ & 286,703 & 286,703 & 286,703 & 277,461 & 277,461 & 277,461 \\
\hline
\end{tabular}

Notes: Standard errors are in parentheses; significance levels are in square brackets. In addition the variables shown, all models include the mother's age at her first birth, a calendar time trend, the state/maternity cohort dummies, and a full set of dummies for elapsed duration. 
Table 7

Actual and Simulated Proportions of Initially Unwed White Mothers Who Marry, by Length of Time since First Birth

\begin{tabular}{|c|c|c|c|c|c|c|}
\hline \multirow{2}{*}{$\begin{array}{l}\text { Definition of } \\
\text { Benefits: } \\
\text { Time since } \\
\text { lst birth }\end{array}$} & \multicolumn{3}{|c|}{ State of Residence in 1980} & \multicolumn{3}{|c|}{ State of Child's Birth } \\
\hline & $\begin{array}{l}\text { Baseline } \\
\text { Logistic } \\
\text { (1) }\end{array}$ & $\begin{array}{c}\text { Benefits } \\
10 \% \text { higher } \\
\text { (2) }\end{array}$ & $\begin{array}{c}\text { Benefits } \\
10 \% \text { lower } \\
\text { (3) }\end{array}$ & $\begin{array}{l}\text { Baseline } \\
\text { Logistic } \\
\text { (4) }\end{array}$ & $\begin{array}{l}\text { Benefits } \\
10 \% \text { higher } \\
\text { (5) }\end{array}$ & $\begin{array}{c}\text { Benefits } \\
10 \% \text { lower } \\
\text { (6) }\end{array}$ \\
\hline 1 year & 30.0 & 28.4 & 31.7 & 30.0 & 28.4 & 31.5 \\
\hline 3 years & 53.9 & 51.5 & 56.8 & 54.1 & 51.8 & 56.3 \\
\hline 5 years & 68.5 & 66.1 & 70.9 & 68.1 & 65.8 & 70.4 \\
\hline
\end{tabular}

Notes: Figures in columns (1), (2), and (3) are based on the model reported in column (1) of Table 4. Figures in columns (4), (5), and (6) are based on the model reported in column (2) of Table 4. 
Table 8

Actual and Simulated Proportions of Initially Unwed Black Mothers with Subsequent Births, by Length of Time since First Birth

\begin{tabular}{|c|c|c|c|c|c|c|}
\hline $\begin{array}{l}\text { Definition of } \\
\text { Benefits: }\end{array}$ & \multicolumn{3}{|c|}{ State of Residence in 1980} & \multicolumn{3}{|c|}{ State of Child's Birth } \\
\hline $\begin{array}{l}\text { Time since } \\
\text { 1 st birth }\end{array}$ & $\begin{array}{c}\text { Baseline } \\
\text { Logistic } \\
\text { (1) }\end{array}$ & $\begin{array}{l}\text { Benefits } \\
10 \% \text { higher } \\
(2)\end{array}$ & $\begin{array}{c}\text { Benefits } \\
10 \% \text { lower } \\
\text { (3) }\end{array}$ & $\begin{array}{c}\text { Baseline } \\
\text { Logistic } \\
\text { (4) }\end{array}$ & $\begin{array}{c}\text { Benefits } \\
10 \% \text { higher } \\
(5)\end{array}$ & $\begin{array}{l}\text { Benefits } \\
10 \% \text { lower } \\
\text { (6) }\end{array}$ \\
\hline 2 year & 19.7 & 20.9 & 18.6 & 20.0 & 21.1 & 19.0 \\
\hline 5 years & 50.2 & 52.5 & 48.0 & 50.9 & 52.9 & 48.9 \\
\hline 7 years & 61.8 & 63.1 & 58.5 & 61.6 & 63.7 & 59.5 \\
\hline
\end{tabular}

Notes: Figures in columns (1), (2), and (3) are based on the model reported in column (3) of Table 4. Figures in columns (4), (5), and (6) are based on the model reported in column (4) of Table 4. 


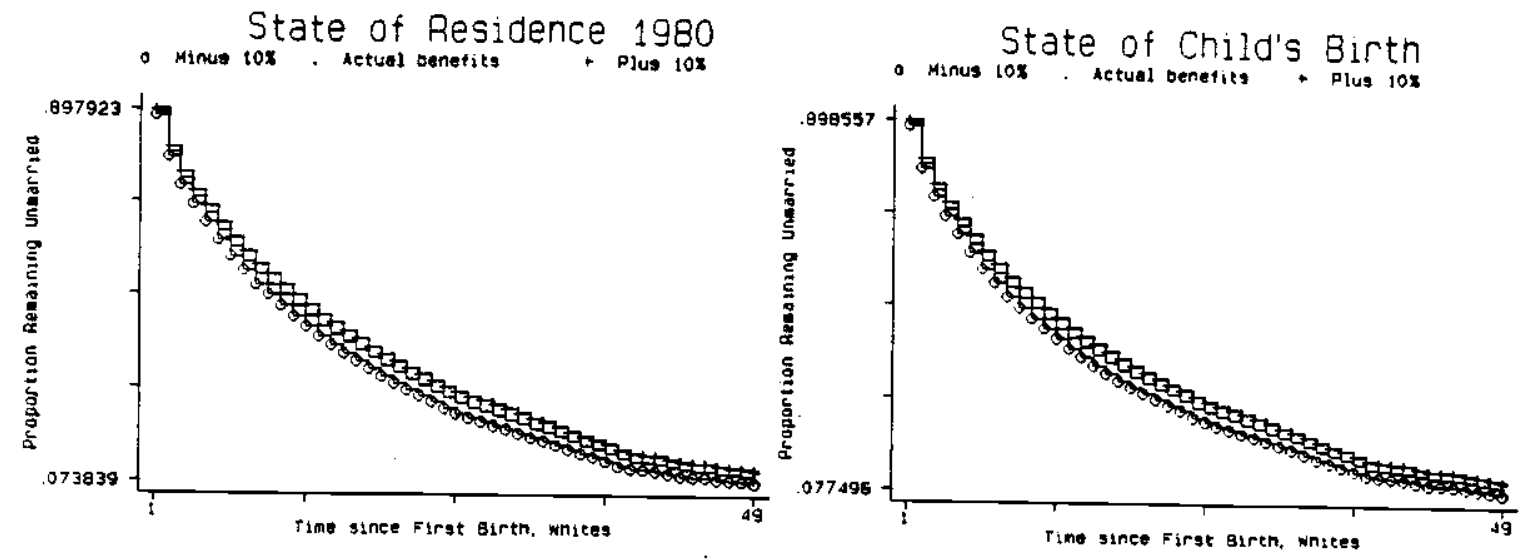

Figure 1: Survivor Functions, Time-to-First-Marriage 


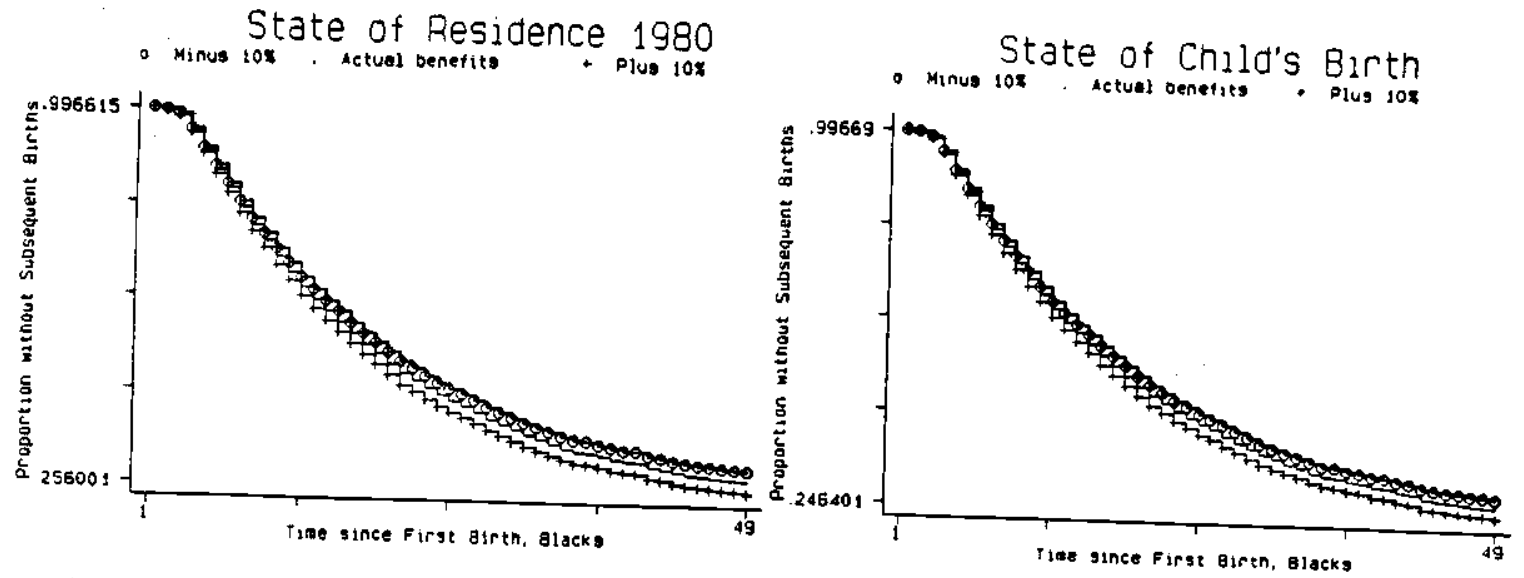

Figure 2: Survivor Functions, Time-to-First-Birth 